\title{
Influence of Suboptimal Hydration on the Immune Response
}

\author{
Dorothée Chabas \\ Neuroesthetics, San Francisco, CA, USA
}

\section{Keywords}

Hydration · Hypertonicity $\cdot$ Immunity $\cdot$ Multiple sclerosis

\begin{abstract}
Background: A healthy immune system is a subtle orchestration of the innate and adaptive immune systems that efficiently detect and process foreign antigens while tolerating the self. The influence of hypertonicity on the immune system is poorly understood [1-16]. Summary: In vitro studies suggest that hypertonicity influences innate and adaptive immunity on several cellular and molecular levels. This influence tends to be pro-inflammatory, but not always. Other cofactors include the duration of exposure to hypertonicity (chronic versus acute), the location in the body, and the timing with priming of the immune system. Recent publications about high salt diet in vitro and in animal models of multiple sclerosis (MS) suggest an influence on the TH17 autoimmune pathway, that does not translate into the human disease in vivo. Key Messages: The influence of hypertonicity on the immune system is complex and depends on multiple factors, such as temporality with immune priming and length of exposure. Since findings in animal models did not always translate into human diseases, further studies are needed to specify the consequences of acute or chronic hy-
\end{abstract}

pertonicity in healthy subjects or patients with autoimmune diseases such as MS. Further studies need to be conducted in animal models and in humans to better understand the influence of suboptimal hydration on the immune system and on autoimmune diseases, and address its clinical relevance.

(c) 2022 The Author(s)

Published by S. Karger AG, Basel

\section{Acknowledgements}

Dr. Jodi Stookey reviewed this original presentation.

\section{Conflict of Interest Statement}

Dr. Dorothée Chabas was hired as a consultant by Danone to prepare and present this work at the 2021 Hydration for Health conference.

\section{Funding Sources}

Dr. Dorothée Chabas was hired as a consultant by Danone to prepare and present this work at the 2021 Hydration for Health conference.
Correspondence to:

Dorothée Chabas, dorothee@ chanezon.com 


\section{References}

1 Stookey JD, Allu PKR, Chabas D, Pearce D, Lang F. Hypotheses about sub-optimal hydration in the weeks before coronavirus disease (COVID-19) as a risk factor for dying from COVID-19. Med Hypotheses. 2020;144: 110237.

2 Kølsen-Petersen J. Immune effect of hypertonic saline: fact or fiction? Acta Anesthesiol Scand. 2004;48(6):667-78.

3 Ciesla DJ, Moore EE, Zallen G, Biffl WL, Silliman CC. Hypertonic saline attenuation of polymorphonuclear neutrophil cytotoxicity: timing is everything. J Trauma. 2000;48(3): 388-95.

4 Pascual JL, Ferri LE, Seely AJE, Campisi G, Chaudhury P, Giannias B, et al. Hypertonic saline resuscitation of hemorrhagic shock diminishes neutrophil rolling and adherence to endothelium and reduces in vivo vascular leakage. Ann Surg. 2002;236(5):634-42.

5 Mitra S, Schiller D, Anderson C, Gamboni F, D’Alessandro A, Kelher M, et al. Hypertonic saline attenuates the cytokine-induced proinflammatory signature in primary human lung epithelia. PLoS One. 2017;12(12): e0189536.
6 Yi B, Titze J, Rykova M, Feuerecker M, Vassilieva G, Nichiporuk I, et al. Effects of dietary salt levels on monocytic cells and immune responses in healthy human subjects: a longitudinal study. Transl Res. 2015;166(1):103-10.

7 Mickleborough TD, Lindley MR, Ray S. Dietary salt, airway inflammation, and diffusion capacity in exercise-induced asthma. Med Sci Sports Exerc. 2005;37(6):904-14.

8 Kølsen-Petersen JA, Nielsen JO, Bendtzen K, Tonnesen E. Infusion of hypertonic saline $(7.5 \% \mathrm{NaCl})$ causes minor immunological changes in normovolaemic women. Acta Anaesthesiol Scand. 2004;48(2):224-33.

9 Schatz V, Neubert P, Schröder A, Binger K, Gebhard M, Müller DN, et al. Elementary immunology: $\mathrm{Na}+$ as a regulator of immunity. Pediatr Nephrol. 2017;32:201-10.

10 Alberdi M, Iglesias M, Tejedor S, Merino R, López-Rodríguez C, Aramburu J. Contextdependent regulation of Th17-associated genes and IFN $\gamma$ expression by the transcription factor NFAT5. Immunol Cell Biol. 2017; 95(1):56-67.
11 Wu C, Yosef N, Thalhamer T, Zhu C, Xiao S, Kishi Y, et al. Induction of pathogenic TH17 cells by inducible salt-sensing kinase SGK1. Nature. 2013;496(7446):513-7.

12 Kleinewietfeld M, Manzel A, Titze J, Kvakan $\mathrm{H}$, Yosef N, Linker RA, et al. Sodium chloride drives autoimmune disease by the induction of pathogenic TH17 cells. Nature. 2013. 496(7446):518-22.

13 Na SY, Janakiraman M, Leliavski A, Krishnamoorthy G. High-salt diet suppresses autoimmune demyelination by regulating the blood-brain barrier permeability. Proc Natl Acad Sci U S A. 2021;118(12):e2025944118.

14 Ascherio A, Munger KL. People with MS should consume a low-salt diet - NO. Mult Scler. 2016;22(14):1779-81.

15 Farez MF, Fiol MP, Gaitán MI, Quintana FJ, Correale J. Sodium intake is associated with increased disease activity in multiple sclerosis. J Neurol Neurosurg Psychiatry. 2015; 86(1):26-31.

16 Cvetkovic L, Perisic S, Titze J, Jäck HM, Schuh $\mathrm{W}$. The impact of hyperosmolality on activation and differentiation of B lymphoid cells. Front Immunol. 2019;10:828. 